\title{
Detection, transmission and pathogenicity of fungi on Blepharocalyx salicifolius (H.B.K.) Berg. seeds ${ }^{1}$
}

\author{
Suelen Santos Rego ${ }^{2 *}$, Álvaro Figueredo dos Santos 3 , \\ Antônio Carlos Nogueira², Yoshiko Saito Kuniyoshi ${ }^{2}$
}

\begin{abstract}
The objective of this study was to identify the fungi associated with the fruit and seeds of Blepharocalyx salicifolius and verify their transmission and pathogenicity to seeds and seedlings. Fungal identification on seeds was made using the blotter test and potato-dextroseagar but only the blotter test was used for fruit. Fungal transmission to seedlings was evaluated using four replications of 50 seeds planted in vermiculite. The pathogenicity of the fungi, Colletotrichum sp., Curvularia sp., Cladosporium sp. Pestalotia sp. and Macrophomina sp. was tested. Potentially pathogenic and saprophytic fungi were found on the fruits and seeds. The transmission of Cladosporium sp. from seeds to seedlings was verified, and Cladosporium sp. Pestalotia sp. and Macrophomina sp. were found to be pathogenic to B. salicifolius seedlings.
\end{abstract}

Index terms: seed pathology, forest seeds, diseases.

\section{Detecção, transmissão e patogenicidade de fungos em sementes de Blepharocalyx salicifolius (H.B.K.) Berg.}

\begin{abstract}
RESUMO - Objetivou-se nesse trabalho identificar os fungos associados aos frutos e sementes de Blepharocalyx salicifolius e sua transmissão e patogenicidade às sementes e plântulas. A identificação dos fungos nas sementes foi realizada pelos métodos de "blotter test" e batatadextrose-ágar e para os frutos foi utilizado somente o "blotter test". Para verificar a transmissão dos fungos para as plântulas foram semeadas quatro repetições de 50 sementes em vermiculita. Testou-se a patogenicidade dos fungos Colletotrichum sp., Curvularia sp., Cladosporium sp., Pestalotia sp. e Macrophomina sp. Nos frutos e sementes foram encontrados fungos potencialmente patogênicos e saprófitas. Verifica-se transmissão do fungo Cladosporium sp. das sementes para as plântulas, e os fungos Cladosporium sp., Pestalotia sp. e Macrophomina sp. foram patogênicos às plântulas de $B$. salicifolius.
\end{abstract}

Termos para indexação: patologia de sementes, sementes florestais, doenças.

\section{Introduction}

Blepharocalyx salicifolius, commonly known as "murta" in Portuguese, is common in riparian forests (Lorenzi, 1998), and is one of the most common species of the Myrtaceae to be found in mixed ombrophilous forest (Legrand and Klein, 1978). This species may be used for landscaping (Lorenzi, 1998) and for planting along river margins since it occurs naturally in these situations and attracts seed-dispersing birds (Carvalho, 2006).

${ }^{1}$ Submitted on $07 / 04 / 2010$. Accepted for publication on 05/30/2011.

${ }^{2}$ Departamento de Floresta, UFPR, 80210-170 - Curitiba, PR, Brasil.
Tree size varies widely (4 to $30 \mathrm{~m}$ ), with a generally straight trunk and a DBH (diameter at breast height) which can reach $40 \mathrm{~cm}$ (Carvalho, 2006; Lorenzi, 1998; Marchiori and Sobral, 1997; Landrum, 1986).

The need to expand forestry areas has led to increased interest in native Brazilian tree species. However, there are problems in seedling production due to a lack of information since healthy seedling production depends on knowing the health and quality of the seed used (Carneiro, 1987; Mendes et al., 2005).

${ }^{3}$ Embrapa Floresta, Caixa Postal 319, 83411-000 - Colombo, PR, Brasil.

*Corresponding author < suelen_srego@yahoo.com.br> 
The study of fungi associated with the seeds of forestry species is important for developing a basis for epidemiological models, for seed storage and for seedling production (Santos et al., 2000). Fungal attack on seeds can cause various kinds of diseases or damage, including: seed wrinkling size reduction, seed rotting, necrosis, discoloration and a reduction in viability and germination (Araújo and Rossetto, 1987). Among the diseases transmitted by forestry seeds are damping-off, which is one of the most common diseases observed in seedlings (Smith, 1970), and caused by various fungi, including: Fusarium sp., Rhizoctonia sp., Pythium sp., Phytophthora sp., Cylindrocladium sp., Sclerotium sp., Botrytis sp., Curvularia sp., Pestalotia sp. and Diplodia pinea. This disease affects seeds at germination and also recently-emerged seedlings (Carneiro, 1987; Catie, 1991; Smith, 1970; Boyce, 1961).

Other descriptions of pathogens transmitted by seeds can be found in the literature, and cause diseases in native forestry species, including, Fusarium solani and Pestalotiopsis sp. on Mimosa caesalpiniaefolia (Mendes et al., 2005) and Fusarium oxysporum and Rhizoctonia solani on Bixa orellana (Santos et al., 1992). Pathogens causing damage at germination, include Phoma sp. and Phomopsis sp. on seeds of Tabebuia serratifolia and Anadenanthera perigrina (Coêlho et al., 1996); Phomopsis sp. on Dipteryx alata (Santos et al., 1997); Fusarium sp., Phomopsis sp. and Colletotrichum sp. on Anadenanthera colubrina and Piptadenia paniculata (Rego et al., 2006).

Netto and Faiad (1995) observed a high incidence of pathogenic and saprophytic fungi on seeds of Didymopanax morototoni and Virola sebifera, which was probably one of the factors responsible for the seed deterioration and the low percentage of germination.

Fungi on seeds can cause serious damage during storage, especially when conditions are unsuitable. The growth of storage fungi, such as Aspergillus sp. and Penicillium sp., cause a loss of germinative power, an increase in the quantity of fatty acids provoked by the oxidation of oils, and also seed warming due to an increase in the respiration rate, resulting in faster seed deterioration (Machado, 1988).

Due to the above and the importance of evaluating the association of fungi with seeds, the objective of this study was to identify the fungi associated with the fruits and seeds of $B$. salicifolius and verify their transmission and pathogenicity to seeds and seedlings.

\section{Material and Methods}

B. salicifolius fruits were collected from 12 donor trees at Colombo, Paraná state, in 2007. Seeds were extracted by macerating and washing the fruits in running water and they were then dried on paper towels under laboratory conditions for 24 hours (mean maximum temperature of 23- $24{ }^{\circ} \mathrm{C}$, minimum of $12-13^{\circ} \mathrm{C}$ and mean of $17-18^{\circ} \mathrm{C}$ ).

Detection of fungi on fruits and seeds: two methods were used to detect fungi on seeds: incubation on a paper substrate ('blotter test') and plating on an agar medium (PDA). For the blotter test, four repetitions of 100 seeds were distributed on two sheets of sterilized filter paper, moistened with sterilized distilled water and placed in plastic boxes ('gerbox'), previously disinfected with $1 \%$ sodium hypochlorite. In the PDA test, four repetitions of 50 seeds were disinfected with $70 \%$ alcohol and $1 \%$ sodium hypochlorite for 30 seconds, washed in sterilized distilled water and distributed in sterilized Petri dishes containing PDA culture medium. Fungi associated with the fruits were detected by using the blotter test with four repetitions of 50 fruits.

The seeds and fruits were incubated for seven days under a 12 hour black light/ 12 hour no light photoperiod at a temperature of $20 \pm 1{ }^{\circ} \mathrm{C}$. Fungal structures were observed under a stereoscopic and optical microscope and identified with the help of an identification key (Barnett and Hunter, 1982).

Transmission of seed fungi to seedlings: Four repetitions of fifty seeds were sown on isopor seed trays containing a vermiculite medium and kept in a greenhouse with daily irrigation. The percentage emergence and number of seedlings with symptoms were evaluated. The seedlings with symptoms and non-germinated seeds were disinfected with $70 \%$ alcohol and $1 \%$ sodium hypochlorite for 30 seconds before washing in sterilized distilled water. They were then placed on two sheets of sterilized filter paper, moistened with sterilized distilled water in a gerbox previously disinfected with $1 \%$ sodium hypochlorite, and maintained for seven days to detect pathogens.

Pathogenecity test: the potentially phytopathogenic fungi, Colletotrichum sp., Curvularia sp., Cladosporium sp., Pestalotia sp. and Macrophomina sp., detected by the blotter test and PDA, were isolated on an agar medium and then replicated on other plates to purify them. The fungal cultures were incubated in a BOD chamber at $20^{\circ} \mathrm{C}$ for ten days. After the incubation period, the fungi were inoculated on the seeds with the fungal culture using the contact method. The seeds were previously disinfected with $70 \%$ alcohol and $1 \%$ sodium hypochlorite for 30 seconds and washed in sterilized distilled water. Four repetitions of 25 seeds were then placed in contact with the fungal cultures and the control only in contact with the PDA medium, and 
maintained for 24 hours at $20^{\circ} \mathrm{C}$. The inoculated seeds were sown on isopor seed trays containing a vermiculite medium and kept in a greenhouse with daily irrigation.

The percentage of dead seedlings, percentage emergence, mean emergence time (MT) (Laboriau, 1983) and the emergence velocity index (EVI) were evaluated (Maguire, 1962). Those seedlings with symptoms and non-emerged seeds were collected and incubated in a wet chamber for seven days to verify the presence of the inoculated fungi.

The experimental design was completely random. The means of the percentage fungal incidence were submitted to Bartlet's test and analysis of variance, and the means compared with Tukey's test at the 5\% probability level. The data on percentage emergence, mean time, emergence velocity index and percentage of dead seedlings were submitted to the Kruskal-Wallis test and the means compared by nonparametric multiple comparisons at the $5 \%$ probability level.

\section{Results and Discussion}

Detection of fungi on fruits and seeds: the following potentially pathogenic fungi were found: Cladosporium sp., Colletotrichum sp., Curvularia sp., Macrophomina sp. and Pestalotia sp., and also the saprophytic fungi: Rhizopus sp. and Trichoderma sp. However, Trichoderma sp. only occurred on the fruits and Curvularia sp., Rhizopus sp. and Macrophomina sp. only occurred on the seeds (Table 1). The percentage occurrence of these fungi was low for both fruits and seeds. Only Cladosporium sp. had a higher incidence on the fruits (7\%) compared to the seeds $(2.5 \%)$ (Table 1$)$.

Table 1. Incidence of fungi on fruits and seeds of Blepharocalyx salicifolius.

\begin{tabular}{lccc}
\hline \multirow{2}{*}{\multicolumn{1}{c}{ Fungi }} & \multicolumn{3}{c}{ Incidence (\%) } \\
\cline { 2 - 4 } & Fruits & \multicolumn{2}{c}{ Seeds } \\
\cline { 2 - 4 } & Blotter test & Blotter test & PDA \\
\hline Rhizopus sp. & 0.0 & 0.0 & 2.5 \\
Trichoderma sp. & 1.0 & 0.0 & 0.0 \\
Cladosporium sp. & $7.0 \mathrm{a}$ & $2.5 \mathrm{~b}$ & $2.5 \mathrm{~b}$ \\
Colletotrichum $\mathrm{sp}$. & $4.5 \mathrm{a}$ & 0.0 & $0.5 \mathrm{a}$ \\
Curvularia sp. & 0.0 & 0.5 & 0.0 \\
Macrophomina $\mathrm{sp}$. & 0.0 & 0.0 & 1.0 \\
Pestalotia sp. & $2.5 \mathrm{a}$ & $3.8 \mathrm{a}$ & $5.0 \mathrm{a}$ \\
\hline
\end{tabular}

Row means followed by distinct letters differ between themselves according to the Tukey test at the $5 \%$ probability level.
The fungi, Cladosporium sp. and Pestalotia sp. were found on both fruits and seeds, demonstrating a possible transmission of these fungi from fruits to seeds since the interior of the fruits acts as a wet chamber, resulting in the establishment and development of fungi inside the fruits, consequently affecting the seeds. The fruit wall may even serve as a nutritional base for the invasion of the seeds by fungi (Menten and Bueno, 1987).

Transmission of seed fungi to seedlings: the seeds of $B$. salicifolius showed $97.5 \%$ emergence with only three dead seedlings. Only one of the three dead seedlings placed in the wet chamber showed growth of Cladosporium sp., demonstrating a low transmission of this fungus from the seed to the $B$. salicifolius seedling. No fungal growth was observed on ungerminated seeds.

According to Toledo and Marcos-Filho (1977) and Machado (1988), there are several factors limiting the efficiency of pathogen transmission by seeds. Each pathogen has specific requirements of temperature, humidity, oxygen, quantity of nutrients, mechanical injury, seed age and the presence of antagonistic microorganisms on the seed. This may have occurred with the pathogens present on the $B$. salicifolius seeds, which were not transmitted to the seedlings because of a lack of favorable conditions of temperature, humidity, oxygen, nutrients and/or the presence of antagonistic microorganisms.

Although Mendes et al. (2005), Nascimento et al. (2006) and Ruiz Filho et al. (2004) observed potentially pathogenic fungi associated with seeds, they did not observe any fungal transmission from the seeds to the seedlings of Mimosa caesalpiniaefolia, Pterogyne nitens and Cedrela fissilis. According to the last author, even though fungal transmission from the seeds to the seedlings was not observed, it is known that fungi can cause damage both in storage, at germination and during subsequent growth stages. Rego et al. (2006) verified the transmission of Fusarium sp. from the seeds to the seedlings of Piptadenia paniculata and Anadenanthera colubrina.

Pathogenicity test: there was a significant difference for the percentage seedling emergence between seeds inoculated with Colletotrichum sp. (81\%) and Curvularia sp. (98\%) (Table 2). It was observed that Colletotrichum sp. reduced seed emergence. The fungus, Colletotrichum sp., has been observed to reduce germination of Anadenanthera colubrina and Piptadenia paniculata seeds (Rego et al., 2006). 
Table 2. Percentage emergence, emergence velocity index (EVI), mean time (MT), and percentage of dead seedlings of Blepharocalyx salicifolius seeds inoculated with different fungus species.

\begin{tabular}{lcccc}
\hline \multicolumn{1}{c}{ Fungi } & Emergence (\%) & EVI & MT & Dead Seedlings (\%) \\
\hline Control & $92.0 \mathrm{AB}$ & $0.27 \mathrm{~A}$ & $88.8 \mathrm{~A}$ & 0.0 \\
Colletotrichum $\mathrm{sp}$. & $81.0 \mathrm{~B}$ & $0.24 \mathrm{~A}$ & $85.6 \mathrm{~A}$ & 0.0 \\
Cladosporium $\mathrm{sp}$ Pestalotia sp. & $97.0 \mathrm{AB}$ & $0.29 \mathrm{~A}$ & $90.4 \mathrm{~A}$ & 4.0 \\
Curvularia sp. & $97.0 \mathrm{AB}$ & $0.29 \mathrm{~A}$ & $88.1 \mathrm{~A}$ & 3.0 \\
Macrophomina $\mathrm{sp}$. & $98.0 \mathrm{~A}$ & $0.27 \mathrm{~A}$ & $92.9 \mathrm{~A}$ & 0.0 \\
\hline
\end{tabular}

Means followed by distinct letters differ between themselves according to the non-parametric multiple comparison test at the $5 \%$ probability level.

No significant difference was observed for any of the treatments for emergence velocity index and mean time data and, therefore, none of the fungi inoculated had any influence on these factors in seedlings.

The fungi Cladosporium sp., Pestalotia sp. and Macrophomina sp. caused leaf burning and seedling death to seedlings originating from inoculated seeds. Pestalotia sp. was also observed to cause wilting and leaf spots on Mimosa caesalpiniaefolia seedlings (Mendes et al., 2005).

\section{Conclusions}

Potentially pathogenic fungi were found on the fruits and seeds of B. salicifolius, including: Cladosporium sp., Colletotrichum sp., Curvularia sp., Macrophomina sp. and Pestalotia sp., and the saprophytic fungi: Rhizopus sp. and Trichoderma sp.

The transmission of Cladosporium sp. from seeds to seedling was observed and the fungi, Cladosporium sp., Pestalotia sp. and Macrophomina sp. are pathogenic to $B$. salicifolius seedlings.

\section{References}

ARAÚJO, E.; ROSSETO, E.A. Doenças e injúrias de sementes. In: SOAVE, J.; WETZEL, M.M.V.S. Patologia de sementes. Campinas: Fundação Cargill, 1987. p.146-161.

BARNETT, H.L.; HUNTER, B.B. Illustrated genera of imperfect fungi. 3.ed. Minnesota: Burgess, 1982. 242p.

BOYCE, J.S. Forest pathology. McGraw-Hill Book Company, 1961. 572p.

CARNEIRO, J.S. Testes de sanidade de sementes de essências florestais. In: SOAVE, J.; WETZEL, M.M.V.S. Patologia de sementes. Campinas: Fundação Cargill, 1987. p.386-394.
CARVALHO, P.E.R. Espécies arbóreas brasileiras. v.2. Colombo: Embrapa Florestas, 2006. 627p.

CATIE. Plagas y enfermedades forestales em América Central: guia de campo. Turrialba: CATIE, 1991. 260p.

COÊLHO, R.M.S.; CASTRO, H.A.; MENEZES, M. Patogenicidade de Phomopsis e Phoma associados a sementes de ipê (Tabebuia serratifolia) e angico vermelho (Anadenanthera perigrina). Summa Phytopathologica, v.22, n.3/4, p.224-227, 1996.

LABORIAU, L.G. A germinação das sementes. Washington: Secretaria Geral da Organização dos Estados Americanos, 1983. 174p.

LANDRUM, L.R. Campomanesia, Pimenta, Blepharocalyx, Legrandia, Acca, Myrrhinium, and Luma (Myrtaceae). Flora Neotropica, n.45, p.116-160, 1986 .

LEGRAND, D.C.; KLEIN, R. Mirtáceas. Flora Ilustrada Catarinense, I, v.17-22, p.576-580, 1978.

LORENZI, H. Árvores Brasileiras: manual de identificação e cultivo de plantas arbóreas nativas do Brasil. 2.ed. Nova Odessa: Plantarum, 1998. 352p.

MACHADO, J.C. Patologia de sementes: fundamentos e aplicações. Brasília: MEC-ESAL-FAEPE, 1988. 106p.

MAGUIRE, J.D. Speed of germination aid in selection and evaluation for seedling emergence and vigor. Crop Science, v.2, n.1, p.176-177. 1962.

MARCHIORI, J.N.C.; SOBRAL, M. Dendrologia das Angiospermas: myrtales. Santa Maria: UFSM, 1997. 304p.

MENDES, S.S.; SANTOS, P.R.; SANTANA, G.C.; RIBEIRO, G.T.; MESQUITA, J.B. Levantamento, patogenicidade e transmissão de fungos associados às sementes de sabiá (Mimosa caesalpiniaefolia Benth). Revista Ciência Agronômica, v.36, n.1, p.118-122, 2005. http://www.ccarevista.ufc.br/seer/index.php/ccarevista/article/ viewFile/14/15

MENTEN, J.O.M.; BUENO, J.T. Transmissão de patógenos pelas sementes. In: SOAVE, J.; WETZEL, M.M.V.S. Patologia de sementes. Campinas: Fundação Cargill, 1987. p.164-189. 
NASCIMENTO, W.M.O.; CRUZ, E.D.; MORAES, M.H.D.; MENTEN, J.O.M. Qualidade sanitária e germinação de sementes de Pterogyne nitens Tull. (Leguminosae-Caesalpinioideae). Revista Brasileira de Sementes, v.28, n.1, p.149-153, 2006. http://www.scielo.br/pdf/rbs/v28n1/a21v28n1.pdf

NETTO, A.M.; FAIAD, M.G.R. Viabilidade e sanidade de sementes de espécies florestais. Revista Brasileira de Sementes, v.17, n.1, p.75-80, 1995. http://abrates.org.br/revista/artigos/1995/v17n1/artigo13.pdf

REGO, S.S.; SANTOS, A.F.; MEDEIROS, A.C.S.; Detecção, transmissão e patogenicidade de fungos em sementes e mudas de angico e angicobranco. Summa Phytopathologica, v.32, suplemento, p.63, 2006.

RUIZ FILHO, R.R.; SANTOS, A.F.; MEDEIROS, A.C.S.; JACCOUD FILHO, D.S. Fungos associados às sementes de cedro. Summa Phytopathologica, v.30, n.4, p.494-496, 2004.

SANTOS, G.R.; ARAÚJO, E.; BRUNO, R.L.A. Investigações preliminares sobre a detecção e patogenicidade da micoflora de sementes de urucu (Bixa orellana L.). Revista Brasileira de Sementes, v.14, n.1, p.13-15, 1992. www.abrates.org.br/revista/artigos/1992/v14n1/artigo04.pdf
SANTOS, M.F.; RIBEIRO, W.R.C.; FAIAD, M.G.R.; SANO, S.M. Fungos associados às sementes de baru (Dipteryx alata Vog.). Revista Brasileira de Sementes, v.19, n.1, p.135-139, 1997. www.abrates.org.br/ revista/artigos/1997/v19n1/artigo25.pdf

SANTOS, A.F.; GRIGOLETTI JÚNIOR, A.; AUER, C.G. Transmissão de fungos por sementes de espécies florestais. Revista Floresta, v.30, n.1/2, p.119-128, 2000. http://ojs.c3sl.ufpr.br/ojs2/index.php/floresta/ article/view/2360/1972

SMITH, W.H. Tree pathology: a short introduction. New York: Academic Press, 1970, 309p.

TOLEDO, F.F.; MARCOS-FILHO, J. Manual das sementes: tecnologia e produção. São Paulo: Agronômica Ceres, 1977. 224p. 